\title{
MENINGKATKAN KEMAMPUAN BERPIKIR KREATIF MATEMATIS DAN HABITS OF MIND SISWA SMA MELALUI PENDEKATAN CONTEXTUAL TEACHING AND LEARNING
}

\author{
Diana Wijayanti ${ }^{1)}$ Nurpradesa Maulida ${ }^{2)}$, Masta Hutajulu ${ }^{3)}$, Heris Hendriana ${ }^{4)}$ \\ 12)334) Program Studi Pendidikan Matematika, IKIP Siliwangi Bandung \\ wijayantidiana62@gmail.com ${ }^{1)}$
}

\begin{abstract}
Abstrak
Penelitian ini bertujuan untuk mengetahui pencapaian dan peningkatan kemampuan berpikir kreatif matematis siswa SMA. Siswa SMA masih merasakan kesulitan dalam belajar matematika terlebih mempelajari materi trigonometri. Oleh karena itu, penelitian ini menggunakan pendekatan contextual teaching and learning agar siswa dapat lebih mudah memahami materi yang dianggap sulit tersebut. Melalui habits of mind siswa dapat terbiasa dalam berpikir kreatif dalam menyelesaikan permasalahan trigonometri dalam kehidupan sehari-hari. Penelitian ini merupakan penelitian eksperimen dengan isntrumen penelitian yang digunakan adalah tes kemampuan berpikir kreatif dan skala habits of mind yang diberikan kepada kelas eksperimen dan kelas kontrol. Penelitian ini dilakukan pada siswa kelas X di SMAN 15 Bandung. Berdasarkan hasil penelitian, diketahui bahwa pencapaian kemampuan berpikir kreatif yang memperoleh pembelajaran dengan pendekatan contextual teaching and learning lebih baik dibandingkan dengan siswa yang memperoleh pembelajaran biasa. Peningkatan kemampuan berpikir kreatif yang menggunakan pendekatan contextual teaching and learning lebih baik dibandingkan dengan siswa yang memperoleh pembelajaran biasa. Dan habits of mind siswa yang menggunakan pendekatan contextual teaching and learning lebih baik dibandingkan siswa yang memperoleh pembelajaran biasa.

Kata Kunci: Kemampuan Berpikir Kreatif Matematis, Habits of Mind, pendekatan Contextual Teaching and Learning
\end{abstract}

Abstract
This research aims to determine the achievement and improvement of the creative
thinking mathematics ability of high school students. High school students still feel the
difficulty in learning mathematics to learn trigonometry material. Therefore, this research
uses contextual teaching and learning approach so that students can more easily
understand the material that is considered difficult. Through habits of mind students can
get used to creative thinking in solving trigonometric problems in everyday life. This
research is an experimental research with research instrument that used is a test of creative
thinking ability and habits of mind scale given to experiment class and control class. This
research was conducted on the students of class X in SMAN 15 Bandung. Based on the
results of the research, it is known that the achievement of creative thinking ability that
obtains learning with contextual teaching and learning approach is better than the students
who get regular learning. The improvement of creative thinking ability using contextual
teaching and learning approach is better compared to students who get regular learning.
And the habits of mind of students using contextual teaching and learning approaches are
better than those with conventional learning.
Keywords: Creative Thinking Mathematics, Habits of Mind, Contextual Teaching, and
Learning.

JES-MAT P-ISSN 2460-8904, E-ISSN 2621-4202

CProgram Studi Pendidikan Matematika 


\section{PENDAHULUAN}

Matematika sering dianggap sebagai mata pelajaran yang sulit dan membosankan bagi siswa. Begitu pula bagi guru, matematika dianggap sebagai pelajaran yang sulit untuk diajarkan. Sebagaimana yang diungkapkan oleh Wahyudin (2008 :338) bahwa matematika merupakan mata pelajaran yang sulit untuk diajarkan maupun dipelajari. Salah satu alasan mengapa demikian adalah karena dalam mempelajari materi baru dalam matematika seringkali memerlukan pengetahuan dan pemahaman yang memadai tentang satu atau lebih materi yang telah dipelajari sebelumnya.

Prestasi pada mata pelajaran matematika secara internasional yang dilakukan oleh lembaga seperti Programme for International Student Assesment (PISA) menunjukkan bahwa Indonesia berada pada peringkat bawah. Hasil ini terlihat dari skor rata-rata internasional sebesar 500, Indonesia menduduki peringkat 39 dari 41 negara dengan perolehan skor rata-rata 367 pada tahun 2000, peringkat 38 dari 40 negara dengan perolehan skor rata-rata 360 pada tahun 2003, peringkat 50 dari 57 negara dengan perolehan skor rata-rata 391 pada tahun 2006, dan peringkat 61 dari 65 negara dengan perolehan skor rata-rata 371 pada tahun 2009 .

Berdasarkan hasil evaluasi tersebut penurunan perolehan terjadi pada tahun 2009. Salah satu penyebabnya adalah kompetensi yang diujikan dalam tes ini jarang diperoleh siswa Indonesia. Kompetensi yang diujikan dalam PISA lebih menghacu pada pemahaman, penalaran dan proses berpikir matematika tingkat tinggi. Hal ini bertolak belakang dengan evaluasi pada bertaraf nasional, siswa diberikan jenis tes yang bersifat objektif (pilihan banyak).

Dengan kata lain, sistem evaluasi nasional saat ini lebih mendorong siswa pada kegiatan menjawab benar saja tanpa memperhatikan proses dan pemahaman. Selain itu, soal yang diberikan dalam proses pembelajaran lebih fokus pada masalah rutin sehingga proses berpikir tingkat tinggi belum tersentuh.

Menurut Mahmudi (Setiawati 2014) peran dan tanggungjawab institusi pendidikan pada saat ini belum optimal. Pendapat ini didukung dengan temuan hasil penelitian yang dilakukan oleh Mc. Gregor di Amerika. Dia menemukan dua pertiga warga Amerika berusia antara 16 tahun sampai dengan 25 tahun tidak dibekali dengan kemampuankemampuan yang berguna untuk menghadapai tantangan dalam kehidupan. Kemampuan kemampuan tersebut di antaranya adalah kemampuan berpikir kreatif dan melakukan pemecahan masalah (Mc. Gregor, 2007).

Selain representasi dan abstraksi, mahasiswa juga dituntut ntuk berpikir kreatif. Berpikir kreatif terlihat ketika seseorang memiliki kemampuan dalam menilai sesuatu dari sudut pandang yang berbeda (Hutajulu dan Minarti 2017). Namun, kemampuan berpikir kreatif mahasiswa masih tergolong rendah. Banyak siswa yang masih mengalami kesulitan jika diberikan bentuk soal yang bersifat divergen dan non-rutin.

Penelitian ini terfokus pada kemampuan berpikir kreatif matematis dan Habits of Mind (HOM). Pada dasarnya, kebiasaan berpikir (habits of mind) matematis disingkat HOM adalah disposisi matematis esensial yang perlu dimiliki oleh dan dikembangkan khususnya pada siswa 
yang mempelajari kemampuan matematis tingkat tinggi (High Order Mathematical Thinking disingkat HOMT). Dan kemampuan berpikir kreatif matematis termasuk ke dalam kemampuan matematis tingkat tinggi (HOMT).

Seperti hasil penelitian dari Hutajulu dan Minarti (2017) bahwa habits of mind mahasiswa yang menggunakan pendekatan keterampilan metakognitif lebih baik daripada mahasiswa yang menggunakan pembelajaran biasa. Kesimpulan dari penelitian tersebut bahwa habits of mind siswa perlu ditingkatkan lagi untuk mengasah kemampuan berpikir kreatif matematis pada jenjang mahasiswa atau siswa SMA.

Pemilihan pendekatan pembelajaran yang tepat akan menjadikan kegiatan pembelajaran yang dilaksanakan terasa menyenangkan dan dapat mendorong siswa untuk berperan aktif dalam kegiatan pembelajarannya, sehingga siswa tersebut dapat mengembangkan kemampuan yang dimilikinya. Salah satu alternatif pendekatan yang sesuai dengan kemampuan berpikir kreatif matematis dan habits of mind adalah pendekatan Contextual Teaching and Learning (CTL).

Dengan menggunakan pendekatan Contextual Teaching and Learning (CTL) siswa dapat menemukan materi dan menghubungkannya dengan kehidupan sehari-hari yang akan membuat siswa dapat meningkatkan kebiasaan berpikir kreatif matematis.

\section{LANDASAN TEORI}

\section{Kemampuan Berpikir Kreatif Matematis}

Tingkatan berpikir yang lebih spesifik adalah berpikir kreatif. Berpikir kreatif sebagai kemampuan untuk melihat bermacam-macam kemungkinan penyelesaian terhadap suatu masalah, merupakan bentuk pemikiran yang sampai saat ini masih kurang mendapat perhatian dalam pendidikan (Guilford dalam Munandar. 2009 : 31).

Kemampuan berpikir kreatif adalah keyakinan dan intuisi seseorang berkaitan dengan ide-ide matematis yang dipersiapkan untuk menyusun strategi dalam menyelesaikan masalah matematis menurut Runco (dalam Setiawati 2014).

Munandar (Winarti 2015) menjelaskan ciri-ciri keterampilan berpikir kreatif adalah sebagai berikut: 1) Keterampilan berpikir lancer (fluency), 2) Keterampilan berpikir luwes (flexibility), 3) Keterampilan berpikir orisinil (originality), 4) Keterampilan berpikir rinci (elaboration).

\section{Habits of Mind}

Kebiasaan berpikir (habits of mind) matematis disingkat HoM adalah disposisi matematis esensial yang perlu dimiliki oleh dan dikembangkan khususnya pada siswa yang mempelajari kemampuan matematis tingkat tinggi (High Order Mathematical Thinking disingkat HOMT).

ed., 2001) mengemukakan Pakar Puccio dan Murdock keterampilan afektif yang termuat dalam berpikir kreatif antara lain: merasakan adanya masalah dan peluang, toleran terhadap ketidakpastian, memahami lingkungan dan kekreatifan orang lain, bersifat terbuka, berani mengambil resiko, membangun rasa percaya diri, mengontrol diri, rasa ingin tahu, menyatakan dan merespons perasaan

dan emosi, dan mengantisipasi sesuatu yang tidak diketahui. 
Selanjutnya Costa (Costa, Ed., 2001) mengidentifikasi enam belas kebiasaan berpikir, ketika individu merespon masalah secara cerdas. Keenam belas kebiasaan berpikir (habits of mind) tersebut adalah sebagai berikut: 1) Bertahan atau pantang menyerah, 2) Mengatur kata hati, 3) Mendengarkan pendapat orang lain dengan rasa empati, 4) Berpikir luwes, 5) Berpikir metakognitif, 6) Berusaha bekerja teliti dan tepat, 7) Bertanya dan mengajukan masalah secara efektif, 8) Memanfaatkan pengalaman lama untuk membentuk pengetahuan baru, 9) Berpikir dan berkomunikasi secara jelas dan tepat, 10) Memanfaatkan indera dalam mengumpulkan dan mengolah data, 11) Mencipta, berkhayal, dan berinovasi, 12) Bersemangat dalam merespons, 13) Berani bertanggung jawab dan menghadapi risiko, 14) Humoris, 15) Belajar berkelanjutan, dan 16) Belajar berkelanjutan.

\section{Pendekatan Contextual Teaching and Learning}

Dalam Kamus Besar Bahasa Indonesia (KBBI), kontekstual berarti berhubungan dengan konteks, dimana menurut Alwasilah (2011), "Konteks biasanya disamakan dengan lingkungan, yaitu dunia luar yang dikomunikasikan melalui pancaindra, ruang yang kita gunakan setiap hari". Berdasarkan pengertian tersebut, dapat disimpulkan bahwa kontekstual artinya berhubungan dengan lingkungan.

Istilah kontekstual digunakan pula dalam dunia pendidikan, salahsatunya yaitu dalam pendekatan pembelajaran yang dikenal dengan nama Contextual Teaching and Learning (CTL). "CTL merupakan pendekatan pembelajaran yang menghubungkan konsep dengan konteksnya, sehingga siswa memperoleh sejumlah pengalaman belajar bermakna berupa pengetahuan dan keterampilan" menurut Suwangsih \& Tiurlina (2006).

Sa'ud \& Suherman (2010) menyatakan terdapat tujuh komponen dalam pendekatan kontekstual, yaitu kontruktivisme, inkuiri, bertanya, masyarakat belajar, pemodelan, refleksi, dan penilaian nyata.

\section{METODE PENELITIAN}

\section{Jenis Penelitian}

Penelitian ini dilakukan pada dua kelompok sampel yang terdiri dari satu kelompok eksperimen dan satu kelompok kontrol. Kelompok eksperimen adalah kelompok siswa yang memperoleh pembelajaran dengan pendekatan contextual teaching and learning, sedangkan kelompok kontrol merupakan kelompok siswa yang memperoleh pembelajaran biasa. Selanjutnya pasa awal dan akhir pembelajaran kedua kelas diberi tes dan skala sikap. Desain yang digunakan dalam penelitian ini adalah kuasi eksperimen.

\section{Waktu dan Tempat Penelitian}

Penelitian ini dilakukan pada semester genap tahun pelajaran 2017/2018 di SMAN 15 Bandung.

\section{Subjek Penelitian}

Subjek dalam penelitian ini dikelompokkan dalam 2 kelas yaitu kelas X MIPA yang dijadikan satu kelas eksperimen atau kelompok eksperimen. Sedangkan satu kelas lainnya dijadikan kelas kontrol atau kelompok kontrol. Kelompok tersebut dipilih secara acak. Penentuan sampel dilakukan dengan menggunakan teknik "purposive sampling".

\section{Data, Instrumen, dan Teknik Pengumpulan Data}

Data yang dianalisis berupa skor dari jawaban siswa pada instrumen kemampuan berpikir kreatif dan skala habits of mind yang diberikan sebelum perlakuan/ pembelajaran dengan 
pendekatan contextual teaching and learning diberikan dan setelah semua

Instrumen yang dikembangkan dalam penelitian ini adalah tes tulis dalam bentuk uraian dan skala sikap. Dalam hal ini, tes tulis yang diberikan akan digunakan untuk mengetahui kemampuan siswa dalam berpikir kreatif. Tes tulis ini mengukur aspek berpikir kreatif siswa. Skala sikap yang digunakan dalam penelitian ini bertujuan untuk mengetahui habits of mind siswa terhadap materi trigonometri dengan pendekatan contextual teaching and learning.

\section{Teknik Analisis Data}

Data dalam penelitian ini akan dikumpulkan melalui tes dan angket skala sikap. Data yang berkaitan dengan kemampuan berpikir kreatif matematis siswa dikumpulkan melalui tes. Sementara data habits of mind siswa dalam pembelajaran dengan pendekatan contextual teaching and learning dikumpulkan melalui angket skala sikap.

Data yang dianalisis adalah data kuantitaif berupa hasil tes kemampuan berpikir kreatif matematis siswa dan perlakuan diberikan.

data kualitatif berupa angket untuk siswa. Seluruh data hasil penelitian diolah menggunakan software SPSS 22.0.

\section{HASIL PENELITIAN DAN PEMBAHASAN}

Data kuantitatif diperoleh melalui tes kemampuan berpikir kreatif matematis dan skala habits of mind siswa di awal dan akhir pembelajaran. Dalam penelitian ini diperoleh skor pretes, postes dan N-gain. Skor pretes digunakan untuk mengetahui kemampuan awal mahasiswa sebelum diberikan perlakuan, skor postes digunakan untuk mengetahui kemampuan akhir siswa setelah diberikan perlakuan dan N-gain digunakan untuk mengatahui peningkatan yang terjadi setelah diberi perlakuan.

Berdasarkan hasil skor pretes, postes dan N-gain pada kemampuan berpikir kreatif matematis dan habits of mind siswa yang kana diukur yaitu skor rerata $(\mathrm{x} \overline{)}$, persentase $(\%)$, dan satndar deviasi (sd). Perhitungan statistik deskriptif secara ringkas disajikan dalam Tabel 1.

\section{Tabel 1}

Rekapitulasi Hasil Pretes, Postes dan N-Gain Kemampuan Berpikir Kreatif Matematis serta Habits of Mind Siswa

\begin{tabular}{|c|c|c|c|c|c|c|c|}
\hline \multirow[t]{2}{*}{ Variabel } & \multirow[t]{2}{*}{ Stat } & \multicolumn{3}{|c|}{$\begin{array}{l}\text { Pendekatan Contextual } \\
\text { Teaching and Learning } \\
\qquad(\mathrm{n}=30)\end{array}$} & \multicolumn{3}{|c|}{$\begin{array}{l}\text { Pembelajaran Biasa } \\
\qquad(\mathrm{n}=30)\end{array}$} \\
\hline & & Pretes & Postes & $\mathrm{N}$-gain & Pretes & Postes & $\mathrm{N}$-gain \\
\hline \multirow{3}{*}{ KBKM } & $\bar{x}$ & 7,90 & 25,33 & 0,73 & 6,90 & 17,27 & 0,41 \\
\hline & $\%$ & 24,69 & 79,17 & & 21,56 & 53,96 & \\
\hline & sd & 2,06 & 2,50 & 0,09 & 3,08 & 5,22 & 0,20 \\
\hline \multirow{3}{*}{ HOM } & $\bar{x}$ & 104,07 & 110,47 & 0,103 & 101,87 & 108,03 & 0,100 \\
\hline & $\%$ & 68,46 & 72,68 & & 67,02 & 71,07 & \\
\hline & sd & 8,29 & 3,98 & 0,21 & 9,94 & 5,30 & 0,15 \\
\hline
\end{tabular}

Catatan: Skor ideal KBKM (Kemampuan Berpikir Kreatif Matematis) = 32 Skor ideal $\mathrm{HOM}=152$ 
Tabel 1 menunjukkan bahwa rata-rata hasil pretes pada kelas eksperimen dan kelas kontrol untuk kemampuan berpikir kreatif matematis memiliki perbedaan yang sangat kecil. Untuk kemampuan berpikir kreatif matematis skor pretes di kelas eksperimen $3,13 \%$ lebih tinggi daripada kelas kontrol.

Dari perhitungan hasil postes, rata-rata hasil postes pada kelas eksperimen dan kelas kontrol terlihat berbeda. Skor rata-rata kemampuan berpikir kreatif matematis pada kelas eksperimen adalah 8,06 atau 25,21\% lebih tinggi daripada kelas kontrol, dengan standar deviasi 2,72.

Dari Tabel 1 juga dapat terlihat, skor rata-rata gain ternormalisasi kelas eksperimen dan kelas kontrol untuk kemampuan berpikir kreatif matematis berbeda. Skor rata-rata gain ternormalisasi kemampuan berpikir kreatif matematis siswa pada kelas eksperimen adalah 0,73 dengan standar deviasi 0,09. Sedangkan kelas kontrol skor rata-ratanya adalah 0,41 dengan standar deviasi 0,20.

Pada Tabel 1 tersebut terlihat bahwa rata-rata pretes pada kelas eksperimen dan kelas kontrol untuk kemampuan berpikir kreatif matematis perbedaannya sangat kecil. Hal tersebut menunjukkan kelas kontrol dan kelas eksperimen memiliki kemampuan awal yang sama. Sedangkan rata-rata nilai postes dan $n$ gain kelas eksperimen yang mendapat pembelajaran dengan pendekatan contextual teaching and learning menunjukkan hasil yang lebih baik dibandingkan dengan kelas kontrol yang pembelajarannya secara biasa.

\section{Analisis Skor Pretes dan Postes Kemampuan Berpikir Kreatif Matematis}

Analisis skor menggunakan uji normalitas, dan uji nonparametrik. Dikarenakan data pretes dan postes tersebut tidak berdistribusi normal maka dilanjutkan ke uji nonparametrik Mann-Whitney.

\section{Tabel 2}

\section{Data Hasil Uji Normalitas Pretes dan Postes Kemampuan Berpikir Kreatif Matematis}

Test Statistics $^{\mathrm{a}}$

\begin{tabular}{|l|r|}
\hline & Nilai_Pretes \\
\hline Mann-Whitney U & 371,500 \\
Wilcoxon W & 836,500 \\
Z & $-1,178$ \\
Asymp. Sig. (2-tailed) &, 239 \\
\hline
\end{tabular}

a. Grouping Variable: Kelas

Berdasarkan hasil uji-t di atas didapat nilai $\operatorname{Sig}$ (2-tailed) yaitu 0,239 $>0,05$. Hal ini menunjukkan bahwa Ho diterima. Artinya tidak terdapat perbedaan yang signifikan antara skor pretes kemampuan berpikir kreatif matematis siswa kelas yang menggunakan pendekatan contextual teaching and learning dengan siswa yang menggunakan pembelajaran biasa. Untuk membuktikan bahwa kemampuan akhir kelas eksperimen lebih baik dari kelas kontrol maka dilakukan uji perbedaan rataan skor postes dengan menggunakan uji Mann-Whitney. 
Tabel 3

Data Hasil Uji Perbedaan Skor Postes kemampuan Berpikir Kreatif Matematis Test Statistics ${ }^{\mathrm{a}}$

\begin{tabular}{|l|r|}
\hline & Nilai_Postes \\
\hline Mann-Whitney U & 55,500 \\
Wilcoxon W & 520,500 \\
Z & $-5,859$ \\
Asymp. Sig. (2-tailed) &, 000 \\
\hline
\end{tabular}

a. Grouping Variable: Kelas

Dari hasil uji Mann-Whitney di atas didapat nilai Sig. (2-tailed) yaitu 0,000. Penelitian ini menggunakan hipotesis satu pihak (1-tailed), maka nilai Sig. (2-tailed) harus dibagi menjadi 2 yaitu $0,000 / 2=0,00$. Karena nilai signifikansi $0,00<0,05$ maka Ho ditolak. Artinya pencapaian kemampuan berpikir kreatif matematis siswa yang mendapat pembelajaran menggunakan pendekatan contextual teaching and learning lebih baik daripada yang menggunakan pembelajaran biasa.

\section{Analisis Skor Gain Ternormalisasi Kemampuan Berpikir Kreatif Matematis}

Hasil Uji Normalitas dan Uji Signifikansi Perbedaan Rata-rata Gain Kemampuan Berpikir Kreatif Matematis

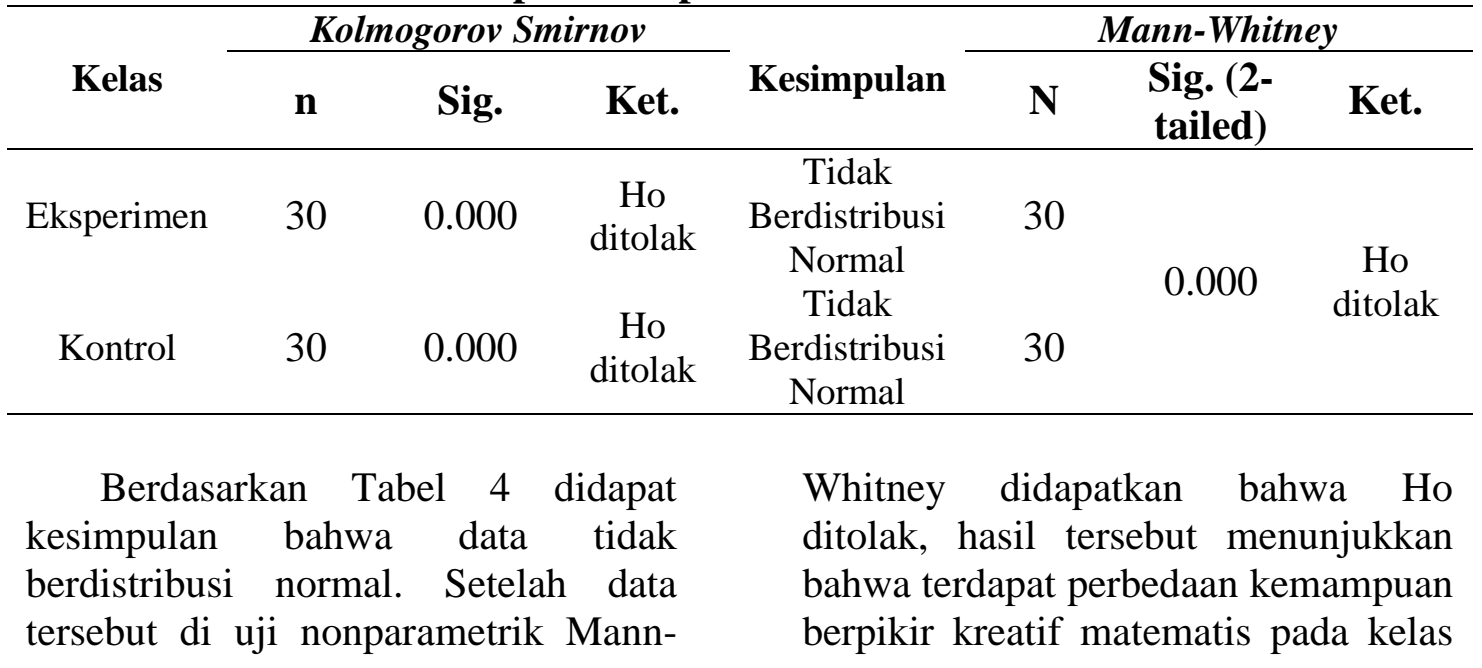
ternormalisasi kemampuan berpikir kreatif matematis menggunakan data gain ternormalisasi. Data gain ternormalisasi juga menunjukkan klasifikasi peningkatan skor siswa yang dibandingkan dengan skor maksimal idealnya.

Untuk membuktikan bahwa skor gain ternormalisasi kemampuan berpikir kreatif matematis siswa yang pembelajarannya menggunakan pendekatan contextual teaching and learning lebih baik daripada kelas kontrol dengan pembelajaran biasa maka dilakukan uji nonparametrik Mann-Whitney dikarenakan data tidak normal.
Tabel 4 
eksperimen dan kelas kontrol. Artinya bahwa peningkatan kemampuan berpikir kreatif matematis siswa yang mendapatkan pembelajaran dengan pendekatan contextual teaching and learning lebih baik daripada siswa yang mendapatkan pembelajaran biasa.

\section{Analisis Skala Habits of Mind}

Analisis skor skala habits of mind menggunakan uji normalitas, uji homogenitas, lalu lanjut ke uji-t. Berikut penjabarannya.

Tabel 5

Data Hasil Perbedaan Rataan Pretes Habits of Mind

\begin{tabular}{cccc}
\hline \multicolumn{3}{c}{ t-test for Equality of Means } & Interpretasi \\
\cline { 1 - 3 } $\mathbf{t}$ & $\mathbf{d f}$ & Sig. (2-tailed) & \\
\hline 0,931 & 58 & 0,356 & Ho diterima \\
\hline
\end{tabular}

Dari hasil uji- $t$ di atas didapat nilai $\operatorname{Sig}(2$-tailed) yaitu $0,239>0,05$. Hal ini menunjukkan bahwa Ho diterima. Artinya tidak terdapat perbedaan yang signifikan antara skor pretes kemampuan berpikir kreatif matematis siswa kelas yang menggunakan pendekatan contextual teaching and learning dengan siswa yang menggunakan pembelajaran biasa.

Untuk membuktikan bahwa kemampuan akhir kelas eksperimen lebih baik dari kelas kontrol maka dilakukan uji perbedaan rataan skor postes dengan menggunakan uji Mann-Whitney

\section{Tabel 6}

Data Hasil Uji Perbedaan Rataan Postes Habits of Mind

\begin{tabular}{|c|c|c|c|}
\hline & & & Postes_HOM \\
\hline Mann-Whitney U & & & 309,000 \\
\hline Wilcoxon W & & & 774,000 \\
\hline Z & & & $-2,099$ \\
\hline Asymp. Sig. (2-tailed) & & & ,036 \\
\hline \multirow[t]{3}{*}{ Monte Carlo Sig. (2-tailed) } & Sig. & &, $034^{\mathrm{b}}$ \\
\hline & $95 \%$ Confidence Interval & Lower Bound & ,030 \\
\hline & & Upper Bound & ,038 \\
\hline \multirow[t]{3}{*}{ Monte Carlo Sig. (1-tailed) } & Sig. & &, $015^{\mathrm{b}}$ \\
\hline & $95 \%$ Confidence Interval & Lower Bound & ,013 \\
\hline & & Upper Bound &, 017 \\
\hline
\end{tabular}

a. Grouping Variable: Kelas

b. Based on 10000 sampled tables with starting seed 2000000 .

Dari Tabel 6 diperoleh hasil Monte Carlo Sig. (1-tailed) yaitu $0,015<$ 0,05 . Hal ini menunjukan bahwa Ho ditolak, maka dapat disimpulkan bahwa terdapat perbedaan habits of mind siswa pada akhir pembelajaran setelah perlakuan diberikan pada kelas eksperimen. Oleh karena itu 
pencapaian habits of mind siswa yang pembelajarannya menggunakan pendekatan contextual teaching and learning lebih baik daripada yang menggunakan pembelajaran biasa.

\section{Analisis Skor Gain Ternormalisasi Habits of Mind}

Analisis skor gain ternormalisasi habits of mind menggunakan data gain ternormalisasi. Data gain ternormalisasi juga menunjukkan klasifikasi peningkatan skor siswa

Tabel 7

Hasil Uji Normalitas dan Uji Signifikansi Perbedaan Rata-rata Gain Kemampuan Berpikir Kreatif Matematis

\begin{tabular}{|c|c|c|c|c|c|c|c|}
\hline \multirow[b]{2}{*}{ Kelas } & \multicolumn{3}{|c|}{ Kolmogorov Smirnov } & \multirow[b]{2}{*}{ Kesimpulan } & \multicolumn{3}{|c|}{ Mann-Whitney } \\
\hline & $\mathbf{n}$ & Sig. & Ket. & & $\mathbf{N}$ & $\begin{array}{l}\text { Sig. (2- } \\
\text { tailed) }\end{array}$ & Ket. \\
\hline Eksperimen & 30 & 0.004 & $\begin{array}{c}\text { Ho } \\
\text { ditolak }\end{array}$ & $\begin{array}{c}\text { Tidak } \\
\text { Berdistribusi } \\
\text { Normal }\end{array}$ & 30 & 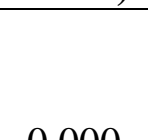 & Но \\
\hline Kontrol & 30 & 0.004 & $\begin{array}{c}\text { Ho } \\
\text { ditolak }\end{array}$ & $\begin{array}{c}\text { Tidak } \\
\text { Berdistribusi } \\
\text { Normal }\end{array}$ & 30 & 0.000 & ditolak \\
\hline
\end{tabular}

Berdasarkan Tabel 7 didapat kesimpulan bahwa data tidak berdistribusi normal. Setelah data tersebut di uji nonparametrik MannWhitney didapatkan bahwa Ho ditolak, hasil tersebut menunjukkan bahwa terdapat perbedaan habits of mind siswa pada kelas eksperimen dan kelas kontrol. Artinya bahwa peningkatan habits of mind siswa yang mendapatkan pembelajaran dengan pendekatan contextual teaching and learning lebih baik daripada siswa yang mendapatkan pembelajaran biasa.

\section{SIMPULAN DAN SARAN}

\section{Simpulan}

Berdasarkan hasil analisis penelitian yang telah dibahas, maka diperoleh kesimpulan sebagai berikut:
1. Pencapaian kemampuan berpikir kreatif matematis siswa yang yang dibandingkan dengan skor maksimal idealnya.

Untuk membuktikan bahwa skor gain ternormalisasi habits of mind siswa yang pembelajarannya menggunakan pendekatan contextual teaching and learning lebih baik daripada kelas kontrol dengan pembelajaran biasa maka dilakukan uji nonparametrik Mann-Whitney dikarenakan data tidak normal. pembelajarannya menggunakan pendekatan contextual teaching and learning lebih baik daripada siswa yang menggunakan pembelajaran biasa.

2. Peningkatan kemampuan berpikir kreatif matematis siswa yang menggunakan pendekatan contextual teaching and learning lebih baik daripada siswa yang menggunakan pembelajaran biasa.

3. Habits of mind siswa yang pembelajarannya menggunakan pendekatan contextual teaching and learning lebih baik daripada yang menggunakan pembelajaran biasa.

\section{Saran}

Berdasarkan hasil penelitian direkomendasikan beberapa hal sebagai berikut:

1. Pendekatan contextual teaching and learning dapat digunakan sebagai salah satu pembelajaran untuk 
meningkatkan kebiasaan berpikir siswa

2. Memberikan permasalahan yang berkaitan dengan kehidupan sehari-hari yang akan membiasakan siswa berpikir kreatif

3. Dikarenakan terdapat perbedaan pencapaian dan peningkatan maka diperlukan untuk lebih meningkatkan pembelajaran dengan pendekatan dan kemampuan yang lainnya

4. Bagi pemerhati pendidikan atau seorang pendidik dapat menggunakan pendekatan contextual teaching and learning dan kemampuan berpikir kreatif matematis juga habits of mind dalam pembelajaran matematika.

\section{DAFTAR PUSTAKA}

Alwasilah, A. Chaedar. (2011).

Pokoknya Kualitatif: DasardasarMerancang dan Melakukan Penelitian

Kualitatif. Jakarta: Dunia Pustaka Jaya.

Costa, A. L dan Garmston, R . J. „Five Human Passion: The Origin of Effective Thinking" dalam A. L. Costa,. (Ed.) (2001). Developing Minds. A Resource Book for Teaching Thinking. 3rd Edidition. Assosiation for Supervision and Curriculum Development. Virginia USA.

Hutajulu, M. \& Minarti, D. E. (2017). Meningkatkan Kemampuan
Advance Mathematical

Thinking dan Habits of Mind

Mahasiswa Melalui

Pendekatan Keterampilan

Kognitif. JES MAT. Vol. 3: No.2.

McGregor, D. (2007). Developing Thinking; Developing Learning A Guide to Thinking Skills in Education. New York: Open University Press McGraw-Hill.

Munandar, U. (2009). Pengembangan Kreativitas Anak Berbakat. Jakarta: Rineka Cipta.

Saud, U. S \& Suherman, A. (2010). Inovasi Pendidikan. Bandung: Alfabeta.

Setiawati, E. (2014). Mengembangkan Kemampuan Berpikir Logis, Kreatif, dan Habits of Mind Matematis Melalui Pembelajaran Berbasis Masalah. Bandung: respository.upi.edu.

Suwangsih dan Tiurlina. (2006). Model Pembelajaran Matematika. Bandung: UPI Press.

Wahyudin. (2008). Pembelajaran dan Model-model Pembelajaran. Bandung: UPI.

Winarti. (2015). Contextual Teaching and Learning (CTL) untuk Meningkatkan Kemampuan Berpikir Kreatif Siswa. JPFK. Volume 1: No. 